\title{
Evaluation of the Uses of Acids and Bases in Daily Life from an Educational Standpoint
}

\author{
Sibel DEMİR KAÇAN \& Dilek ÇELİKLER \\ Department of Elementary Science Education, Faculty of Education \\ Ondokuz Mayıs University, Samsun, Turkey \\ E-mail: sibelfe@hotmail.com / dilekc@omu.edu.tr
}

Received: November 5, 2015 Accepted: Dec. 7, 2015 Published: February 1, 2016

doi:10.5296/jse.v6i1.8649 URL: http://dx.doi.org/10.5296/jse.v6i1.8649

\begin{abstract}
The aim of this study was to determine the level of knowledge of science teacher candidates attending a public university in Northern Turkey about the uses of acids and bases in daily life. The study was performed with 43 first-year student volunteers, from the Department of Science Teaching. The students were asked three open-ended questions that required them to write down examples of where acids and bases are used in daily life, and of the ways in which acids and bases may negatively impact daily life. The study results indicated that all students listed lemon as an example of acid in daily life, and soap as an example of base in daily life. However, it was noted that only a few of the students knew the actual acid and base compounds these items contain. In addition, some of the students described bleach as an acid, illustrating that their knowledge on acids and bases was incorrect. Moreover, some of the students participating to the study were not able to describe the uses of bases in daily life or their possible negative impacts, which indicated a significant lack of knowledge on the subject.
\end{abstract}

Keywords: Acid and base, Science teacher candidate, Daily life, Science education. 


\section{Introduction}

Identifying the relations between science and daily life as a method for understanding science enables students to associate the knowledge gained in classrooms with out-of-school experiences (Wu, 2003). Associating science classes such as chemistry, physics and biology with daily life is not only a strong teaching strategy for teachers, but also an approach that contributes significantly to a meaningful and lasting learning experience (Campbell \& Lubben, 2000; Doğan, Kıvrak \& Baran, 2004; Mayoh \& Knutton, 1997; McCann, 2001). To ensure meaningful learning, students must be able to transfer the scientific concepts they learn to daily life (Campbell \& Lubben, 2000; Kıyıcı \& Aydoğdu, 2011; Martin, 2009). The extent to which students can transfer scientific knowledge to daily life is also an indication of the degree to which their learning is not based on rote memorization (Coştu, Ünal \& Ayas, 2007; Göçmençelebi İlkörücü \& Özkan, 2009; Özmen, 2003). Parnell (1996) similarly describes that, to ensure a better learning experience, the knowledge taught in schools must be associated with and implementable in daily life.

Establishing associations between daily life and chemistry subjects increases the motivation of students towards their classes, and is also effective in instilling or increasing their willingness to learn. Taking this into account, it is possible to say that the chemistry knowledge acquired during education will become meaningful and lasting, to extent that it can be associated with daily life. Based on these considerations, this study attempted to determine how science teacher candidates associated the subject of acids and bases - one of the most fundamental concepts of chemistry - with their daily life experiences and events.

\section{Methodology}

This study was performed with 43 volunteering first-year students attending the Department of Science Teaching of a public university in the Black Sea Region of Turkey. The students were asked three open-ended questions that required them to write down examples of where acids and bases are used in daily life, and of the ways in which acids and bases can negatively impact on daily life. Data analysis was performed using descriptive analysis, and the results were provided in terms of frequency (f).

\section{Results}

The answers provided by the participating science teacher candidates regarding the uses of acids and bases in daily, life were evaluated. The students' responses are given below for each of the three study questions in terms of answer frequency.

\subsection{Are acids used in daily life? If so, please give examples.}

The answers of the participating science teacher candidates regarding the uses of acids in daily life are provided in Table 1. 
Table 1. Frequency distribution of the acids encountered/used by students in their daily lives.

\begin{tabular}{llll}
\hline Example & $\begin{array}{l}\text { Answer } \\
\text { Frequency }\end{array}$ & $\begin{array}{l}\text { Acid } \\
\text { Compound }\end{array}$ & $\begin{array}{l}\text { Answer } \\
\text { Frequency }\end{array}$ \\
\hline Yes & $\mathbf{4 3}$ & & \\
\hline Foods and Beverages & & & 5 \\
\hline Lemon & 43 & Citric acid & 3 \\
\hline Cola & 37 & Carbonic acid & 33 \\
\hline Vinegar & 36 & Acetic acid & - \\
\hline Tea & 26 & - & 6 \\
\hline Soda & 18 & Carbonic acid & - \\
\hline Orange & 18 & - & - \\
\hline Mineral water & 15 & - & 6 \\
\hline Apples & 13 & Malic acid & 4 \\
\hline Strawberry & 12 & Folic acid & 1 \\
\hline Sour salt & 7 & Citric acid & \\
\hline Others & & & - \\
\hline Gastric acid & 24 & Hydrochloric acid & 7 \\
\hline Bleach & 13 & - & - \\
\hline Cleansing materials & 13 & - & 5 \\
\hline Spirit of salt & 12 & Hydrochloric acid & 4 \\
\hline Aqua Fortis & 12 & Nitric acid & 5 \\
\hline Certain Medications & 6 & - & - \\
\hline
\end{tabular}

Table 1 shows that all of the students taking part in this study described acids as having uses in daily life. All of the participating students mentioned lemons as an example of acid from daily life; however, only a few were able to name citric acid as the actual acid compound in lemons. In addition, the majority of the students gave vinegar as an example of acid from daily life, and were able to name acetic acid as its acid compound. There were also many students who described commonly consumed foodstuffs such as cola, tea, soda, and mineral water as examples of acids. However, it was noted that none of the students were able to correctly name the acid compounds in tea and soda. Furthermore, while there were students who mentioned orange, apple and strawberry as examples of acids, only a few were able to describe the acid compounds they contained, with none of the students correctly identifying the acid in oranges. The study results indicate that some of the students also described spirit of salt, aqua Fortis, and gastric acids as further examples of acid in daily life. Some students described bleach as an acid-containing substance, which indicated that their knowledge on acids was erroneous.

\subsection{Are bases used in daily life? If so, please give examples.}

The answers of the participating science teacher candidates regarding the uses of bases in daily life are provided in Table 2. 
Table 2. Frequency distribution of the bases encountered/used by students in their daily lives.

\begin{tabular}{llll}
\hline Example & $\begin{array}{l}\text { Answer } \\
\text { Frequency }\end{array}$ & $\begin{array}{l}\text { Base } \\
\text { Compound }\end{array}$ & $\begin{array}{l}\text { Answer } \\
\text { Frequency }\end{array}$ \\
\hline Yes & $\mathbf{4 3}$ & & \\
\hline Soap & 43 & $\begin{array}{l}\text { Sodium } \\
\text { Hydroxide }\end{array}$ & 22 \\
\hline Cleansing materials & 22 & - & - \\
\hline Detergent & 15 & - & - \\
\hline Bleach & 12 & - & - \\
\hline Shampoo & 7 & - & - \\
\hline Spirit of salt & 6 & - & - \\
\hline
\end{tabular}

Table 2 shows that all of the students taking part in this study described bases as having uses in daily life. All of the participating students mentioned soap as an example of base from daily life; however, only a few were able to name sodium hydroxide as the actual base compound in soap. It was noteworthy that only a few students were able to describe cleansing materials (which include detergents and soaps) as an example of base, while none of the students were able to describe the base compounds in cleansing materials and detergents. Some of the students describe spirit of salt as a base, which indicated that their knowledge on bases was erroneous.

3.3. In your opinion, in which ways can acids and bases have a negative impact on daily life? If so, please give examples

The answers of the participating science teacher candidates regarding the negative impacts of acids and bases in daily life are provided in Table 3.

Table 3. Frequency distribution of the ways in which acids and bases have a negative impact on daily lives.

\begin{tabular}{ll}
\hline Acids & Answer Frequency \\
\hline Damages the skin & 37 \\
Acid rain & 32 \\
Spirit of salt & 20 \\
Aqua Fortis & 18 \\
Strong acids & 16 \\
Bleach & 13 \\
\hline Generate greenhouse cases & 7 \\
\hline Corrode metals & 5 \\
\hline Bases & \\
\hline No opinion & 34 \\
\hline Mixing two different base-containing cleansing materials & 9 \\
might release toxic gases. & \\
\hline
\end{tabular}

Table 3 indicates that most of the students described the skin damage caused by acids as one 
of the ways in which acids and bases can have a negative impact on daily life. Most of these students mentioned acid rain as a possible way in which acids can cause skin damage. Other students mentioned the strong acids used in laboratories as a possible cause of acid-related skin damage. The study results showed that some of the students described bleach as an acid capable of causing skin damage, which indicated erroneous knowledge among these students regarding the concept of acids. Concerning the ways in which bases can have a negative impact on daily life, the majority of the students could not give an example or express an opinion on the subject, while the other students described that mixing two different base-containing cleansing materials might lead to the release of toxic gases; however, these students could not name these base-containing cleansing materials, nor the toxic gases that might be released if they were mixed.

\section{Conclusions}

The study results illustrated that the science teacher candidates were able to cite only a few examples of acids and bases from daily life. Despite the subject of acids and bases being included in both middle school and high school curricula, the students remained unable to associate their learning in these schools with daily life. As described by Osborne \& Freyberg (1985), keeping science classes detached from the daily lives of students leads to the students' perception of science as being a system of unnecessary and unusable information.

Although tea is a commonly consumed beverage in daily life, none of the students were able to name tannic acid as the acid compound in tea. In addition, only a few students were able to describe the acid compounds in gastric acid, spirit of salt and aqua Fortis (which are hydrochloric acid, hydrochloric acid and nitric acid, respectively). These findings indicate that the students could not associate their chemistry knowledge with daily life, which prevented them from using their chemistry knowledge in daily contexts and in providing correct examples from their daily lives.

All of the students taking part in the study mentioned soap as an example of base from daily life; however, we observed that most of these students were not able to identify sodium hydroxide as the base compound in soap. In addition, there were certain students who described bleach as an acid and spirit of salt as a base, indicating that they had erroneous knowledge on the concepts of acids and bases. These results demonstrated that the students were not adequately capable of transferring and reflecting their chemistry knowledge to daily life. This is significant, since scientific knowledge tends to be lasting among students only to the extent that it can be associated with daily life (Coştu, Ünal \& Ayas, 2007; Göçmençelebi İlkörücü \& Özkan, 2009; Özmen, 2003).

Many students described skin damage as one of the ways in which acids can negatively impact on daily life. Most of these students also noted that such acid-related skin damage could occur through acid rain; however, none of the students could actually describe what causes acid rain. This might also be due to the inadequacy of information they acquired in previous stages of their education, as well as the inability to associate their learning with daily life and examples. Concerning bases, most of the students could not describe the ways in which bases have a negative impact on daily life, illustrating that their knowledge on the 
subject was inadequate.

Using acid- and base-containing materials from daily life in learning activities performed within suitable learning environments will help draw the students' interest towards these materials, while also allowing them to be more motivated towards the subject of acids and bases and to associate their learning with daily life. In certain previous studies, materials such as carbonate (Schmidt et al, 2002), cola (Schunk et al., 2008), soap (Martin, 1997), and various cleansing materials (Rossow \& Flint, 2007) have been used in student experiments. Furthermore, transforming learning environments into settings, where ideas and knowledge can be openly discussed, will make it easier for students to associate classes with daily life (Gilbert et al., 2011). Such an approach will facilitate the teaching of scientific knowledge by making associations with daily life, thus resulting in a more meaningful and lasting learning experience for students.

\section{References}

Campbell, B., \& Lubben, F. (2000). Learning science through contexts: Helping pupils make sense of everyday situations. International Journal of Science Education, 22(3), 239-252. http://dx.doi.org/10.1080/095006900289859

Coştu, B., Ünal, S., \& Ayas, A. (2007). Günlük yaşamdaki olayların fen bilimleri öğretiminde kullanılması. Kırşehir Ĕ̆itim Fakültesi Dergisi, 8(1), 197-207.

Doğan, S., Kıvrak, E., \& Baran, Ş. (2004). Lise öğrencilerinin biyoloji derslerinde edindikleri bilgileri günlük hayatla ilişkilendirme düzeyleri. Erzincan Eğitim Fakültesi Dergisi, 6(1), 57-63.

Gilbert., J. K., Bulte, A. M. W. \& Pilot, A. (2011). Concept development and transfer in context-based science education. International Journal of Science Education, 33(6), 817-837. http://dx.doi.org/10.1080/09500693.2010.493185.

Göçmençelebi İlkörücü, Ş., \& Özkan, M. (2009). İlköğretim altıncı sınıf öğrencilerinin fen bilgisi biyoloji konularını günlük yaşamla ilişkilendirme düzeylerinin başarıya etkisi. Kastamonu Ĕ̈itim Dergisi, 17(2), 525-530.

Kıyıcı, F. B., \& Aydoğdu, M. (2011). Fen bilgisi öğretmen adaylarının günlük yaşamları ile bilimsel bilgileri ilişkilendirebilme düzeylerinin belirlenmesi. Necatibey Eğitim Fakültesi Elektronik Fen ve Matematik Ĕ̈itimi Dergisi, 5(1), 43-61.

Martin, D. J. (1997). Science education today, elementary science methods: A constructivist approach. USA: Delmar Pres.

Martin, D. J. (2009). Elementary science methods: A constructivist approach (5th Edition). USA, CA: Cengage Learning.

Mayoh, K., \& Knutton, S. (1997). Using out-of-school experience in science lessons: Reality or rhetoric? International Journal of Science Education, 19(7), 849-867.

McCann, W. S. (2001). Science education and everyday action. Unpublished doctoral 
dissertation, Ohio, USA: The Ohio State University,

Osborne, M., \& Freyberg, P. (1985). Learning in science: Implications of children's knowledge. Auckland, New Zealand: Heinemann.

Özmen, H. (2003). Kimya öğretmen adaylarının asit ve baz kavramlarıyla ilgili bilgilerini günlük olaylarla ilişkilendirebilme düzeyleri. Kastamonu Eğitim Dergisi, 11(2), 317-324.

Parnell, D. (1996). Cerebral context. Vocational Education Journal, 71(3), 233-256.

Rossow, M. \& Flint A. (2007). Wichtige hinweise zum arbeiten mit oxi-reinigern!, Chemkon, 14(2), 91. http://dx.doi.org/10.1002/ckon.200790017.

Schmidt, A. Freienberg., J. \& Flint A. (2002). Backpulver und das prinzip von le chatelier. Chemkon 9(3), 142-143. http://dx.doi.org/10.1002/1521-3730(200207).

Schunk, A. Proske W., Röder J., Jansen W. \& Peper-Bienzeisler, R. (2008). Experimente rund um die cola. Chemkon, 15(3), 137-138. http://dx.doi.org/10.1002/ckon.200890025.

$\mathrm{Wu}, \mathrm{H}$. (2003). Linking the microscopic view of chemistry to real-life experiences: Intertextuality in a high-school science classroom. Science Education, 87(6), 868-891. http://dx.doi.org/10.1002/sce.10090. 